\title{
Household Perception of Ethnic Material Culture in Socio-economic Enterprises in Kanoni and Engari-sya Sub-counties of Kiruhura District, S.W.Uganda
}

\author{
Emmanuel Mutungi ${ }^{1, *}$, Felix Ngunzo Kioli ${ }^{2}$, Benson Azariah Mulemi ${ }^{3}$ \\ ${ }^{1}$ Department of Art and Industrial Design, Faculty of Vocational Studies, Kyambogo University, Uganda \\ ${ }^{2}$ Department of Sociology and Anthropology, School of Social Sciences, Maseno University, Kenya \\ ${ }^{3}$ Department of Social Sciences, Catholic University of Eastern Africa, Kenya
}

Copyright $(C 2015$ by authors, all rights reserved. Authors agree that this article remains permanently open access under the terms of the Creative Commons Attribution License 4.0 International License

\begin{abstract}
The main objective of this study was to evaluate the importance of ethnic material culture particularly basket making and wood carving in household socio-economic enterprises in Kanoni and Engari-sya sub-counties in Kiruhura district, S.W. Uganda. The study reviewed eshekuru and orugari to illustrate the importance of ethnic material culture in household socio-economic enterprises. The study was based on ethnographic data collected from twelve participants using snowball approach. The study findings revealed that household perception of ethnic material culture was based on Western influenced ideologies such as those of education, religion, and mode of governance on one hand and on the other hand, it was based on household cultural pride. Household's perception of appropriate ethnic material culture was one that did not conflict with the Western religious doctrines, education system or prescribed government policies. Moreover, households wanted to keep and use ethnic material culture that made them unique and proud of their traditional cultural values. The study proposed and recommended a policy shift that promotes the use of ethnic material culture in household enterprises because it was found out that most households use it to augment government supported programs.
\end{abstract}

Keywords Households Socio-economic Enterprises, Ethnic Material Culture, Basket Making, Wood Carving

\section{Introduction}

Socio- economic enterprises are household or community run businesses whose goals are basically to achieve social, cultural, community economic or environmental outcomes; and, in addition to earn income (Ridley-Duff)[1]. Unlike for - profit businesses whose aim is maximising profits, socio-economic enterprises aim catering for community needs in a collective manner. Salkie[2] posits that socio-economic enterprises are grassroots, entrepreneurial sector businesses based on democratic values that seek to enhance the social, economic and environmental conditions of communities, often with a focus on their disadvantaged members. Common objectives include: reducing poverty, providing affordable housing, and addressing environmental concerns through social, cultural, educational, employment and lifestyle activities. Many households run household businesses on the model of socio-economic enterprises where the ultimate goal is to augment their living conditions. Most activities households are involved in are more concerned with socio-economic benefits without necessarily attaching any profit considerations. Whereas this could be true and communities think so, there is an implied economic aspect that can be turned into income for profit. In other parts of the world such as Europe, the social economy is a fast-growing sector, significantly outstripping the private sector in terms of job creation (Doherty) [3]

Households in Kanoni and Engari-sya sub-counties are engaged in subsistence livelihoods where baskets and woodcarvings are often used in most homes. AmanigaRuhanga and Iyango[4] while analyzing the socio-economic baseline of communities of Kiruhura district where Kanoni and Engari-sya are found revealed that cattle keeping were the main economic activity, with banana growing and apiary supplementing food security and household incomes. In carrying out their socio-economic activities, households were using several ethnic material culture items, knowledge and systems such as woodcarvings and baskets. Observation in Kanoni and Engari-sya sub-counties revealed that households do not perceive material culture as a contributing factor in their household enterprises. Instead, households integrate ethnic material culture in their activities and regard it as an ordinary means of livelihood. In most cases, households are engaged in either crop growing or animal rearing where they use 
indigenous skills, items and knowledge which are not paid for. Instead, households are concerned with those inputs which they pay for from external sources either because they do not have them or they do not know how to make them. It is in this regard, that households in Kanoni and Engari-sya sub-counties involved in crop growing could not understand for example how ekitara (woven granary) was contributing to their incomes. Households regarded ekitara as a place where they keep their harvest as they wait for a better market price when they would sell. A participant from Engari-sya sub-county said;

I made this granary so that I can preserve my harvest before I sell them. When you do not have a separate and safe place for storage, you are forced to sell your produce immediately because you do not want it damaged or contaminated. Again, harvest kept in a granary dries properly and does not become damp.

Many household members were not aware that ekitara was adding value to their products. In most households, ekitara was one way of preparing for a better market. They were not aware that keeping harvest in ekitara was adding value to products because it allowed proper drying of the harvest and protected it from wet weather. The household's continued use of material culture items revealed that families attach significant importance to these items.

In some households, a room was reserved for ebyanzi (milk pots) and other milk containers. Ebyanzi (Fig.1) are carved out of wood and the emihaiha (lids) (Fig.2) are woven by women. Ebyanzi are kept on a special place platform orugyegye (Fig.3) which symbolizes the culture of the household and which is a source of pride to many Banyankore households. orugyegye is a centre of power in traditional Banyankore, which reflects roles and obligations of each member of a homestead. Ethnography in Kanoni and Engari-sya sub-counties revealed that traditionally orugyegye was located in the middle of a homestead next to enyomoy'akanono (the main support pole of the hut.

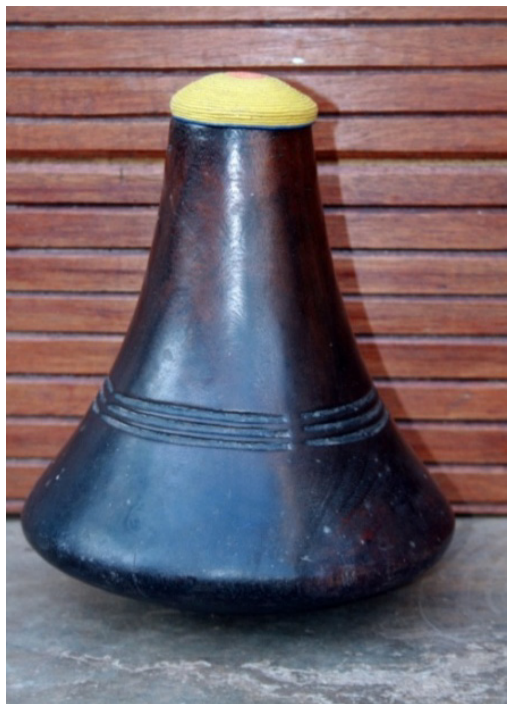

Photo taken by researchers in Bishozi Parish, Engari-sya sub-county

Figure 1. Ekyanzi'

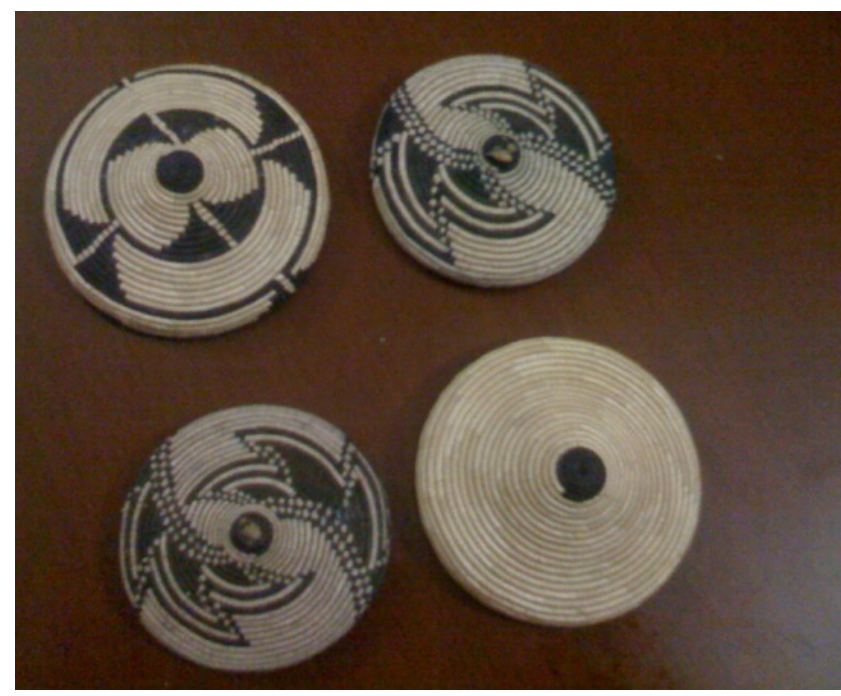

Photo taken by researchers in Bishozi Parish, Engari-sya sub-county

Figure 2. Emihaiha - Milk pot covers

Participants said that Ekyanzi kya'nyineeka (the milk pot in which the head of the family was served) was placed next to that central pole of the house to signify the authority of the man as a head of the family. The other milk pots were then arranged on either sides of ekyanzi kya'nyineeka. Women's special place in the home was next the Orugyegye because that is where women could serve the milk from. This position was important because through it, women were able to participate in family matters; they would know how many cows were milked, which cow had the best milk, or which one had much.

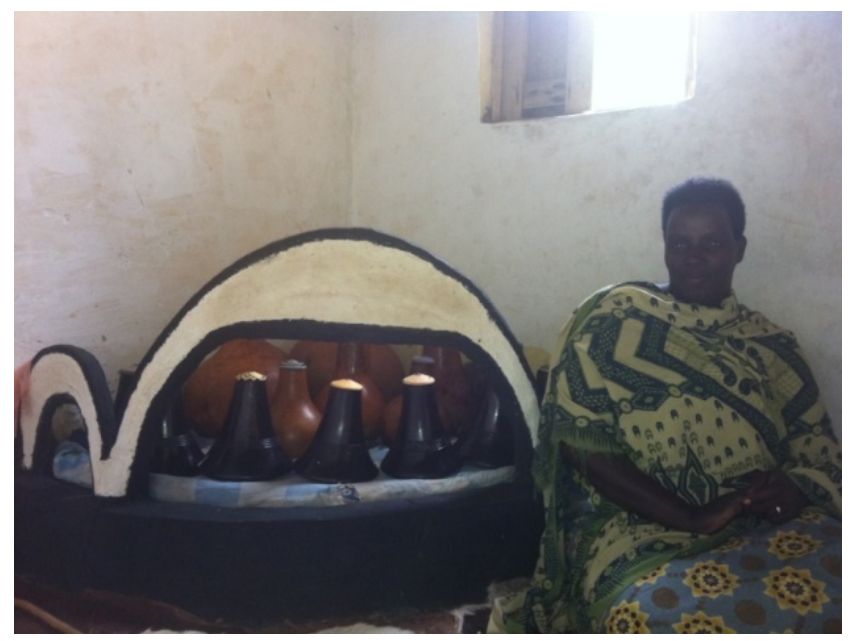

A photo taken by researchers in Engari-sya Sub-county

Figure 3. A woman seated besides orugyegye

\section{Literature Review}

The perceptions of households towards ethnic material culture in socio-economic enterprises follows Boudieu's [5] concept of habitus. The habitus explains the relationship of one's behaviour and practices appropriate to one's role and place in a society. While the habitus is concerned about 
one's surroundings and its impact to one's actions in society, it helps us to understand how communities perceive indigenous materials. In most cases people respond to new experiences which remind them of the past, a past they knew, believed and have experienced and wish to be associated with. It therefore becomes important to understand the context in which people use material culture and then turn it into viable household socio-economic enterprises. This can be achieved by enabling the communities develop their material culture alongside the imported technology and products. Moreover, Miller[6] uses Bourdieu's Outline of Practice to explain that association with everyday practical taxonomies embodied in material culture that result in one belonging to that particular society.

Ethnic material culture forms part of community activities. Ethnic material culture items are either used as an end or means to improve livelihoods. As an end product, these materials are used to serve, store, or prepare household requirements such as food. Items used in this category include milk pots, watering can, mingling stick, spoons, mortar baskets and many others. Those used as means include machetes, carving tools, knives and others. Prown [7] observed that basketry and woodcarving are processes of producing artifacts and means of expressing community values, ideas, attitudes, and assumptions. Households in Kanoni and Engari-sya sub-counties produce these materials not only because they want to sell them but also to improve their livelihoods. Many households want to express their values, ideas and respond to the requirements of contemporary living. Fathers[8] writing on African sculpture observed that traditional African art was a functional and necessary part of everyday life and that it would be impossible to understand African cultures without an understanding of their art. Indeed, participants in Kanoni and Engari-sya produce indigenous materials to make their household enterprises more functional in order to improve their livelihoods. Fathers further observed that in Africa societies, religion, government, education, work and entertainment were all closely inter-related, and that art was deeply woven into the very fabric of social life, thereby playing a central role in binding together all community members. This view illustrates the cultural value society members attach to their material culture. Despite the influence of Western cultures, wood carving and basketry have continued to be practiced among the rural communities because they carry cultural values that bind community members together. In Woodward's [9], Bourdieu[10] explains the aesthetic and culture value of objects which determine their taste and preference basing on social and class objectives that define the parameters of cultural value. The study therefore looked at woodcarving and basketry in Kanoni and Engari-sya sub-counties as objects and symbols of aesthetic value and of self-identity [9]. Moreover, the continued use of material culture items stems from the role such items play in communities. Douglas and Isherwood[11], quoted in Lawrence[12] indicated the importance of material culture items in indigenous communities particularly in making various categories of culture items that lead to sustainable development. Indeed, many of these items continue to guide the process of cultural formation although they are never perceived in economic terms. Apart from servicing the day-to-day activities in a home, in most cases not quantified in terms of household incomes, indigenous materials help in identifying distinct characteristics of various communities and to segregate roles in homes. Most households perceive indigenous materials as a means to assign responsibilities, determine maturity, and instill respect in a way a home or community is run.

The attachment to indigenous materials exhibited by participants is illustrated by Miller[6] who observed that humility of objects gives communities value and they become central in constituting a social order in almost a similar way as education or religion. Research abounds that African gods for instance, are believed to have dwelt in various indigenous ethnic artifacts. It was against such background that when Christianity was introduced and adopted in Uganda in the last quarter of the 19th century, most African material culture was discouraged. They were assumed to be associated with the African gods and therefore in contravention of the doctrine of Christianity. Effah[11] observed that conflicting systems and philosophies have distorted the way Africa perceived the role of material culture in their religion. In most cases, religions from the East and West were insensitive to the cultural value of traditional African objects of worship. Effah further argues that Western European powers grossly affected traditional cultures of indigenous African people leading to loss of their skills, beliefs, social values and customs. That African religion, which originally manifested through material culture, was weakened leading to less production of material culture items [11].

The way people perceive material culture in Kanoni and Engari-sya sub-counties and the entire Ankole region is based on religion (Christianity and Islam) that has been in the area for over a century. The current use of material culture is constructed around the principles of religion. The most practiced religion in the area is Christianity while Islam has few followers. Christianity came to Uganda and Ankole in particular through the Missionaries requested by Kabaka Mutesa I, a king of Buganda who reigned around 1852 to 1884 (Kyeyune[12]; Ssempijja[13]). Christian teachings were always conflicting with traditional beliefs resulting into Christianity regarding African religions ungodly. In Ankole traditional materials were greatly affected by the Revival movement of 1940s. Karamura[14] informs us that the Revival movement became a strong social-religious movement which transformed the cultures of the communities more than what original Christian teaching had done. The movement adopted a model of house to house evangelism which was able to covert many families to Christ. It was and is still referred to as okulokoka (to be saved). This Christian approach to life discouraged the use of traditional items and up to now strict followers of the Revival movement do not use traditional instruments in their worship, 
associating them with satanic worship. This has continued to guide indigenous material production and use. B3, one of the participants said that "when Christianity made us saw the light (okushukururwa), we started putting on clothes, men allowed wives to come into public and to go to school. Christianity brought civilization and development in Ankole".

Many elders in the area actually tend to believe that traditional material culture was idolatry and fetish. Such mind set of elders is as a result of Christian teaching which they converted to and which does not understand and believe in some of African material culture items. However, Although [13] argues that Christianity and Islam did not stop African Traditional Religions because some have continued to exist and many times forming an underlying cultural environment where Africans view the world and make moral decisions, Western religions limited the freedom with which Africans expressed themselves with their religions and material culture in religious acts. Moreover, Strayer [15] observes that some Christianity symbols, techniques, and ideas had similarities with material culture items used in their religion which convinced families to easily accept Christianity. Therefore if this is the case, there is a need to emphasize the importance of material culture in household enterprises because they are pro-development. Put into focus, communities continue to perceive traditional materials largely not as a business but a means to meaningful and sustainable livelihoods. This paper therefore looked at eshekuru and orugari to highlight the importance ethnic material culture in household socio-economic enterprises in Kanoni and Engari-sya sub-counties

\section{Methods}

The study employed ethnography research design. As a qualitative study design of social interactions, behaviours, and perceptions that occur within groups, teams, organizations, and communities (Reeves et el)[16], ethnography was appropriate to the study. Because the study focused on close observation of households perception of wood carving and basket making in Kanoni and Engari-sya sub-counties ethnography became appropriate since it allowed researchers to see beyond what participants perceived in production and use of ethnic material culture items. Furthermore, as Bronislaw Malinowski and Alfred Radcliffe-Brown used ethnography while documenting social arrangements and beliefs of rural communities with whom they lived for a long time [16]; Mulemi [17] observing households use ethnic material culture in household socio-economic enterprises generated useful data. Through close field observation the study analyzed local interpretation and construction of meaning in production and use of material culture (Katebire[18]; Goldbart \& Hustler, [19]), so as to understanding the meaning people make out of production and use of material culture, and how people interpret the continued use of material culture items. As
Singleton at el [20]; Nachmias \& Nachmias, [21]; Singleton \& Straits, [22]; Trochim, [23] \& [18] posit, the study aimed at obtaining a snapshot of household perception of ethnic material culture in a highly economic way of material culture in household enterprises.

\subsection{Study Area}

The study was carried out in Kanoni and Engari-sya sub-counties in Kiruhura district in South Western Uganda. Kanoni and Engari-sya sub-counties are found in Kazo county one of the two counties that form Kiruhura district. Kiruhura district was part of the greater Mbarara district which was sub-divided into districts of Isingiro, Mbarara, Ibanda and Kiruhura.

\subsection{Study Population}

The study population was inhabitants of Kanoni and Engari-sya sub-counties. Kanoni and Engari-sya sub-counties have 8,259 households, with a total population of 44000 people (District Population Office, Kiruhura [24]; Rural Communications Development Fund [25] The population increase is attributed to high fertility levels, high in-migration levels and declining infant child mortality due to immunization. There are many immigrants from other districts of Ankole especially Bushenyi, Rukungiri and Ntungamo who come to the area and acquire small acreage of land for growing crops and keeping animals. According to Uganda Bureau of Statistics (UBOS) [26], the population of Kiruhura district is estimated to be 280,200 persons with a population growth of 3.5 percent per annum. Kanoni and Engari-sya sub-counties together with Kashogi sub-county are the most densely populated sub-counties in Kiruhura Kiruhra district.

\subsection{Sampling Procedure and Sample Size}

As a requirement of ethnography to determine the sample size that gives sufficient saturation of the study in the field. The researchers started the field work with one well-known wood carver and one basket weaver in Kanoni and Engari-sya sub-counties respectively. The respondents were chosen for their relevance to the study objectives rather than their representativeness in the study area. Initial participants in both wood carving and basket making suggested names of other producers and individuals involved in using material culture in household enterprises. The study largely benefited from snowball approach to reach other participants. The total number of participants that were interviewed was 12 and the number was reached when similar answers were got from new respondents which meant that the study had reached a state of theoretical saturation.

\subsection{Data Collection Methods}

Data collection process was phenomenological and 
therefore the researchers employed observation, interviews, collection and reading of cultural artifacts, and also conducted secondary data. The processes the researchers used were helpful because the study wanted to understand the cultural life of the people in the study area. Nachmias and Nachmias[21]; Katebire [18] observe that data collected using observation, interviews, collection and reading of cultural artifacts, and conducting secondary data capture the observed phenomena in their natural setting as they occur and give a researcher direct access to information.

\subsection{Data Analysis}

The analysis of data was carried out following the trends in the patterns that emerged in the course of the research that explained the objective of the study. All interviews were tape recorded and notice taken during the interviews. Thematic analysis, a qualitative method used for 'identifying, analyzing and reporting patterns (themes) within data (Braun \& Clarke[27]) was employed in analyzing the information.

\section{Findings}

In addition to understanding eshekuru and orugari, the study covered other items in wood carving and basketry in household socio-economic enterprises in Kanoni and Engari-sya sub-counties. From six wood carvers and six basket makers, the study gathered data on several items such as Ekyanzi(milk pot), Amaato (troughs) which include Obwaato bw'okunyuuka or Ekinimba/Ekigungiro, Icuba (Watering can), Eshekuru n'omuhini (Mortar and Pestle), Ekitebe (Stool), Orwiiko (mingling pedal) (Omuhini gw'efuka (hoe handle). Ebitenga and Ebitemere (garden baskets), Endiiro (serving baskets), and Emihaiha (milk pot covers). However, we present perceptions as illustrated by eshekuru and orugari

\subsection{Community Perception of Eshekuru}

Eshekuru (Fig. 4) is a household item carved out of specific tree trunk. Eshekuru is a two piece item with the main piece half hollow and the other piece omuhini (a long rounded carved stick used for pounding). The main piece eshekuru is designed with two grooves one at the bottom and the other at the top. The size of the eshekuru depends on the user's preference which is normally determined by the family size. Eshekuru is an important item in preparation of finger millet (Eleusine corocana L) as millet is a staple food for households in Kanoni and Engari-sya sub-counties and for over $50 \%$ of the country's population and increasingly a major source of income (Fetene, et al, [28]; Dramadri, et al.[29]). Millet is harvested from the garden using omusyogw'egyesho (a harvesting knife). The harvested millet is tied in enganda (bundles), carried home to the drying ground in ebitenga (big baskets) and later kept in Ekitara (granary). The study observed that eshekuru is the only device used in removing husks from millet. There was no any other item or method observed during the study through which households were using to separate millet husks from the cereal. Most families that were involved in growing millet owned eshekuru. Families prepared millet using traditional methods and then took it to the grinding machine. There were very few families that still ground millet at home using a grinding stone as used to be the case. Basing on the fact that millet is a staple food to many families means that families have to prepare the millet for home consumption and also for sale. The increase in demand for millet means increased demand for eshekuru, since there is no other technology in the community for separating the millet grain from the husks today. Furthermore, other than preparing millet for home consumption, the increased market for millet requires the use of more than one eshekuru, and possibly a bigger one. This means that eshekuru does not only remain important in preparation of millet for home consumption, but also it becomes important in household enterprises especially for those who produce millet for sale. Contemporary life styles have expanded the utilitarian role of indigenous material culture to include interior decoration. Eshekuru is also displayed as an art work in various homes in towns which gives it an added value.

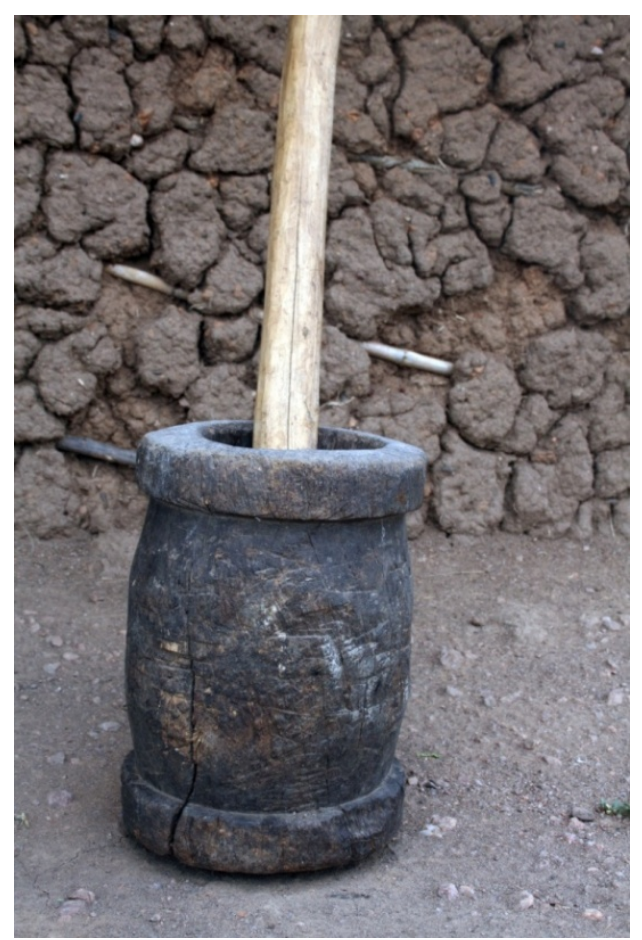

Photo taken by researchers in Nsheshe parish Enagari-sya sub-county

Figure 4. Eshekuru (Mortar and Pestle)

\subsection{Orugari}

The study established that there are several types of garden and food processing baskets used in Kanoni and Engari-sya sub-counties. Among the types of baskets in Kanoni and Engari-sya sub-counties are ekitenga, ekitemere, orugari, and omuhaiha. The baskets are used at different 
stages of food production. The first basket is Ekitenga which is relatively big basket that can contain approximately between $15-25 \mathrm{~kg}$ of grain or seeds. Ekitenga is used to carry farm harvest especially millet from the garden to the drying ground. Ekitenga is also used to harvest millet (Okugyesha). Orugari is used to separate stones, dust or other impurities from the grain during millet preparation. orugari is also used to remove impurities from other foods such as beans or groundnuts. orugari is flexible allowing women to hold it according to what they want to do. orugari was also used while grinding millet in households. orugari was placed in front of the grinding stone and it is on this tray where flour would drop as one grinds. Orugari therefore becomes an important item in household socio-economic enterprises because it plays several tasks in preparation of finger millet for either sale or consumption.

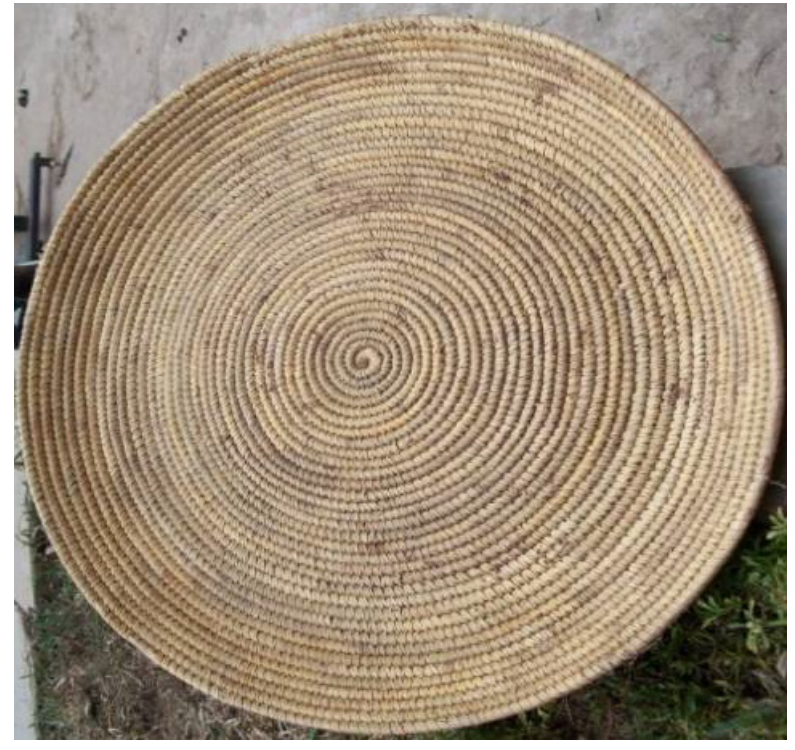

Photo taken by researchers in Kyegando Engarisya sub-county

Figure 5. orugari

\section{Discussion}

The study found out that household in Kanoni and Engari-sya sub-counties perceived ethnic material culture not it terms of its contribution to household enterprises but rather as items that are part of their day to day lives. They were not attaching any economic value to ethnic material culture. Participants and other households in Kanoni and Engairi-sya sub-counties were not aware that ethnic material culture was important in most of their household enterprises. Many household members believed that traditional materials are not part of the inputs they use in their enterprises. Households instead regarded modern technology as the best way for achieving good quality, beauty and means to fit in the global world. Most households perceived modern approaches and technology as the only ones that can help them implement government programs. Ethnic materials were used because households did not have the resources and means to acquire and use modern technologies. Use of traditional ethnic materials was regarded as failure to acquire modern technology and therefore it was regarded as a sign of poverty.

There was social discrimination towards families that were engaged in ethnic material production. Traditional material discourse was rotating on the perceived superiority of the new technology. Households that were able to use modern items were considered successful and were taken as role models in the community. Households that had modernized their life styles in terms of improved farming methods, education attainment and living standards were referred to as abajungu (the Europeans). Households therefore, looked at their ethnic material culture as not so important in improving their livelihoods. On the other hand, the contribution of traditional material in household enterprises was not documented yet many families were relying on it. Neither the local government leaders, opinion leaders nor religious leaders were aware and hence supportive of the idea that ethnic material culture contributes to household socio-economic enterprises.

The conversations with participants showed that indigenous materials were marginalized and communities were not comfortable using them unless one had no alternative. The study found out that households were regarding ethnic material culture as a last resort in their development path because government was not supporting ethnic material culture as a development strategy. There were no substantive support extended to ethnic material items as a development intervention and hence households were regarding it as unimportant development strategy. Consequently, households were not concentrating at developing ethnic material culture as input to household socio-economic enterprise or itself as a socio-economic enterprise.

Research revealed that many households were using ethnic material culture in most of their daily activities. It was also evident that whereas most households were using material culture items, the number of producers of ethnic material culture items was continuously reducing. Many households were relying on buying ethnic items from the producers or the market. Even those that were producing them were old and the young were not willing to learn. The young people preferred to go to school and after look for white collar jobs other than joining a profession negatively perceived. Unlike in the old days when each family member participated in production of items, in contemporary households people regard ethnic materials as archaic. However, they go ahead to use because they are not able to acquire them. This directly influences the marketability of ethnic material culture.

On the other hand, community perception of ethnic material culture was constructed following religious teachings that do not encourage the use of the materials. Although use of indigenous materials and knowledge continue to inform community wellbeing and livelihoods, 
universal religion looks at some of traditional artifacts as fetish. Conversely, the use of these items continues to be rejected by the young generation who are grounded in modern religion. Religion has taken root in the community and it directs community actions in many things. Christian and Islamic activities have over time changed the use of indigenous materials and this gradually affected the appreciation of indigenous materials especially in the young age bracket. In addition, education has also created among the young generation of the western thinking mindset. The syllabus is directed towards Western innovations such as the computers. In Uganda, the current educational trend puts emphasis on the computer laboratories than the art rooms. Contrary to the wish to get people out of poverty, not much was done to empower the communities hence communities continue to rely on indigenous knowledge and skills. Families were using indigenous skills and artifacts in many household enterprises even those that were directly linked to government promoted programs. In addition to inadequate funding for government-led programs that communities were advancing, there were also culture value attached to the production and use of indigenous items. Communities felt that some of these items give them identity and pride as people of that particular culture.

\section{Conclusions}

Household socio-economic enterprises in Kanoni and Engari-sya sub-counties in Kiruhura district, Uganda integrated ethnic material culture (woodcarving and basket making) though households were not aware of its contribution. All households were in one or the other using ethnic material culture either as end resource or as a means to improve their farm activities. The household perceived material through the lens of external factors such as education, religion or government programmes. Households were comfortable to utilize those items that were not in conflict with religion in which most households subscribe to. Families that were producing and using ethnic material were sometime regarded as ungodly. This perception of ungodliness was limiting households to freely produce and use ethnic material culture items. Households of balokole were very reserved because they preferred to use imported items which to them reflected improved livelihoods. Furthermore, households looked at material culture against the Western educational system which emphasizes white collar jobs as opposed to blue collar. Households engaged in production of material culture have the potential to improve their livelihoods because many household were not any more engaged in ethnic material culture production. This means that in the short run, households involved in production of ethnic material culture, had a big market for their products. Moreover, ethnic material culture has been appropriated another meaning as an interior embellishments and artworks. This means that the market for ethnic material culture is expanding both locally and internationally.

\section{Recommendation}

Ethnic material culture which is part of household strengths for survival for centuries should be harnessed in delivering sustainable development strategies because household have a lot of expertise in it. Government should use ethnic material culture as a development pathway because most households have a rich knowledge of ethnic material culture that can be tapped into without using a lot of resources. The fact that household still use ethnic material culture and indigenous knowledge in implementing most government interventions aimed at improving livelihoods, serves as a proof that ethnic material culture is still relevant and positively contributes to household socio-economic enterprises. Moreover, ethnic material culture is shared by most households therefore it would be useful if households are encouraged to use ethnic material culture whose materials for production is easily accessible within the communities. This would reduce on the costs of importation of foreign technology which many households may fail to access due to their limited incomes. The government needs to establish ways in which ethnic material culture can be improved on to meet the demands of the global landscape with will increase the negative perception of material culture as a development pathway.

\section{REFERENCES}

[1] Ridley-Duff, R. J. (2008) Social enterprise as a socially rational business. International Journal of Entrepreneurial Behaviour and Research, 14 (5). 291-312. ISSN 1355-2554

[2] Salkie, F. (2005) Defining the Social Economy, by; Senior Policy Analyst, WD Headquarters, Edmonton

[3] Doherty, B. (2008) Introduction to the landscape of Social Enterprises

http://www.sagepub.com/upm-data/26417_01_Doherty_Ch_ 01.pdf

[4] AmanigaRuhanga, I. \& Iyango, L.(2010) A Socio-economic Baseline Survey of Communities Adjacent to Lake Bisinia/Opeta and Lake Mburo/Nakivale Wetland Systems, UNPD, GEF, IUCN, Uganda Government

[5] Bourdieu, P. (1977). Outline of a Theory of Practice. CUP, Cambridge.

[6] Miller, D. (1987). Material Culture and Mass Consumption. Blackwell, Oxford.

[7] Prown, J.D. (1982). Mind in Matter: An Introduction to Material Culture Theory and Method. Winterthur Portfolio, Vol. 17, No. 1 (Spring, 1982), pp. 1-19, Published by: The University of Chicago Press on behalf of the Henry Francis $\mathrm{du}$ Pont Winterthur Museum, Inc. Stable URL: http://www.jstor.org/stable/1180761

[8] Fathers (1980) African Sculpture from the Collection of the Society Of African Missions Society of African Missions, 
[9] Woodward, K. (2007). Boxing, Masculinity and Identity, The "I" of the Tiger. London: Routledge

[10] Bourdieu (1984) Distinction: A Social Critique of the Judgement of Taste Harvard University Press

[11] Effah, A.,S.,(2009) Christianity and African Traditional Religion in Kumasi: A Comparative Study, M.A Thesis Kwame Nkrumah University of Science and Technology

[12] Kyeyune, G. (2003) Art in Uganda in the $20^{\text {th }}$ Century PhD Thesis School of Oriental and African Studies, University of London

[13] Ssempijja, N. (2011) Glocalizing Catholicism Through Musical Performance Kampala Archdiocesan Post-Primary Schools Music Festivals, PhD Dissertation, University of Bergen

[14] Karamura, G., P. (1998) The interplay of Christianity, Ethnicity and Politics in Ankole, Uganda, 1953-1993. PhD Thesis, University of Leeds

[15] Strayer, R. (1976) Mission History in Africa: New Perspectives on an Encounter, African Studies Review, Vol. 19, No. 1 (Apr., 1976), pp. 1-15 15 Published by: African Studies Association Stable URL: http://www.jstor.org/stable/523849.Accessed: May 15, 2014

[16] Strayer, R. (1976) Mission History in Africa: New Perspectives on an Encounter, African Studies Review, Vol. 19, No. 1 (Apr., 1976), pp. 1-15 15 Published by: African Studies Association Stable URL: http://www.jstor.org/stable/523849.Accessed: May 15, 2014

[17] Mulemi, A.B.(2008) Coping with cancer and adversity Hospital ethnography in Kenya,, African Studies Centre African Studies Collection, vol. 22
[18] Katebire, D.A. (2007) Social Research Methods: An Introduction. Makerere University Printery

[19] Goldbart, Juliet \& David Hustler (2005). Ethnography. In Somekh, Bridget \& Cathy Lewin (eds.) Research Methods in the Social Sciences, (pp. 16-23). New Delhi: Sage.

[20] Singleton, Jr. R.A, Straits, B.C., Straits, M.M.\& McAllister, R.J. (1988).Approaches to Social Research, New York; Oxford University

[21] Nachmias, C.F \& Nachmias, D. (1996). Research Methods in Social Sciences, St Martin's Press, Inc

[22] Singleton, Jr. R. A., \& Straits B.C. (1999).Approaches to Social Research.Third Edition. New York and Oxford: Oxford University Press,

[23] Trochim, W.M.K., (2006) Research Methods, Cornell University

[24] District Population Office, Kiruhura, 2013

[25] Rural Communications Development Fund, 2010

[26] UBOS. (2010). Uganda National Household Survey 2009/2010: Social Economic Module. Abridged Report, Uganda

[27] Braun, V. \& Clarke, V. (2006) Using thematic analysis in psychology. Qualitative Research in Psychology, 3 (2). pp. 77-101. ISSN 1478-0887

[28] Fetene, M., Okori P., Gudu S., Mneney E., Tesfaye K. 2011. Delivering New Sorghum and Finger Millet Innovations for Food Security and Improving Livelihoods in Eastern Africa. Nairobi, Kenya, ILRI.

[29] Dramadri, I.O, Okori, P. \& Wanyera, N. (2012) Diversity of finger millet for crop improvement in Uganda, Makerere University, Kampala Uganda 